\title{
The African indigenous churches' spiritual resources for democracy and social cohesion
}

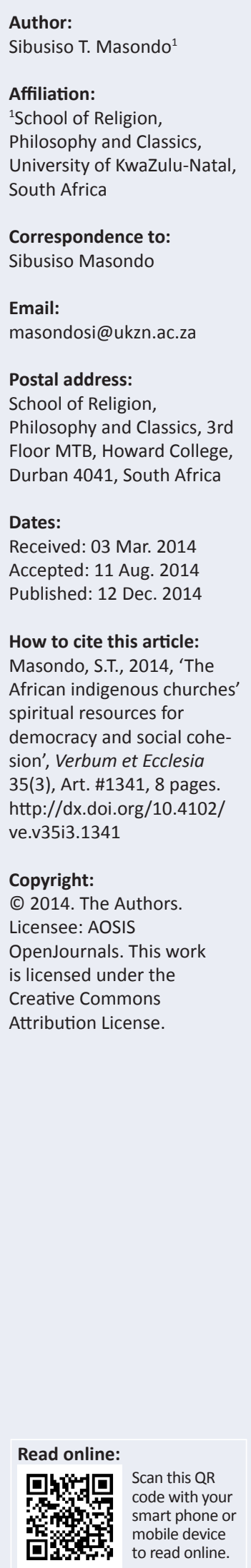

This article outlines resources possessed by the African indigenous churches (AICs) that help them engage with the democratic dispensation and could be used to foster social cohesion in South Africa. It starts off with the premise that social cohesion is that which holds the nation together. The South African rainbow-nation narrative tended to focus on tolerance and the recognition of diversity as strength. Tolerance does not address the fundamental issues that would facilitate cohesion. The idea of cultural justice as advocated by Chirevo Kwenda is seen as the most useful tool to move forward. Cultural justice ensures that all citizens are able to draw on their cultural resources without any fear of being discriminated against. The AICs have an assortment of resources at their disposal that are drawn from African religion, Christianity and Western culture. These resources enable AIC members to appreciate being African and Christian, as well as being South African.

\section{Social cohesion and democracy}

Sociologists Ivor Chipkin and Bongani Ngqulunga (2008:61) defined social cohesion as that which holds a nation together, '... a situation where citizens of a state share feelings of solidarity with their compatriots, and act on the basis of such feelings'. The 1996 South African Constitution acknowledges diversity (of race, culture, religion, sexual orientation), promotes tolerance and is against discrimination of all sorts. Freedom of religion was one of those rights introduced. There was an attempt by the writers of the Constitution to avoid making the same mistakes as the previous regime, namely privileging one religion over others. The Constitution recognises that South Africa is a religiously plural society and thus aims to protect people's rights to belong to any religion without any fear of being discriminated against or persecuted. Religious freedom is also extended to those who hold no religious beliefs. Moreover, the protection of religious freedom should be understood as part of the project of cultivating tolerance in a deeply divided society (Du Plessis 2001:442). However, is tolerance sufficient for social cohesion? Is the fact that people tolerate each other and each other's beliefs enough for society to cohere? Historian of religion Chirevo Kwenda (2003) pushes the issue further by advocating for cultural justice where members of each cultural group are not alienated from the nation-building project. Cultural justice is recognition that '... there is a creative centre in every culture and only from within that centre can people be really influenced' (Nsibande 1992:26).

In fact, we are suffering from a hangover of what historian of religion David Chidester (2000) called the colonial comparative religion, where:

European explorers, travellers, missionaries, settlers, and colonial administrators recorded their findings on indigenous religions all over the world. With remarkable consistency over a period of five hundred years, these European observers reported that they found people in the Americas, Africa and the Pacific Islands who lacked any trace of religion. (p. 427)

This lack of respect and appreciation for African religion has informed, in numerous instances, the way in which African forms of religious thought and experience are treated even in a democratic South Africa.

Section 15 (1) of the Bill of Rights says 'Everyone has the right to freedom of conscience, religion, thought, belief and opinion'. Ebrahim Moosa (2000) holds the view that the South African Constitution has a dualistic view of religion, that is (1) religion as an abstract and unarticulated dogma and (2) religion as practice. The translation of belief into practice is severely limited by the Constitution. The Constitution individualises religion and confines it to a private space. If religion appears in public spaces, it must be regulated in such a way that it does not interfere with the norms and values of the secular state. Individuals can hold beliefs and put them in practice as long as they do not violate the Constitution or the law. In other words, Muslims, African Traditionalists and Hindus can believe in polygamy, but the law will not recognise such unions. 
The same is true for Rastafarians - they can believe in the spiritual power of cannabis (dagga) but it is illegal to possess or smoke it. The state, on its part, cannot afford to allow the practice of forced marriages, ritual murder and other violent crimes in the name of religious practice.

Chipkin and Ngqulunga (2008) concluded that what holds South Africa together is not a single culture, ethnicity or language but a shared commitment to principles of diversity, equality (equity) and justice as enshrined in the Constitution. For Kwenda (2003:78), difference is neither an impediment nor a hindrance to social cohesion as '... if approached with mutual respect and the spirit of reciprocity, it can yield profound social benefits. Indeed, it can be the basis of social cohesion'.

\section{African indigenous churches}

The African indigenous churches exemplify the African struggle for self-identification and self-realisation. During the apartheid era, grown-up African men were treated as overgrown children by their white employers. It was only within the context of the church where they rose to the position of prominence and respectability. African Theologian Gabriel Setiloane (1986), commenting on the role of the Methodist practice and religiosity in the rise and proliferation of African indigenous churches (AICs), made the point that:

... I as a Methodist minister have also witnessed these very people (their brothers in every respect) transformed into people of worth, responsibility, spiritual gifts and charisma as 'stewards' of the church away from the intimidation and humiliation of the white man boss and police. I have lived with men suffering under the stigma of: 'John', 'Piet', or 'Joseph' the whole day as 'tea boy', 'messenger boy' or downright unskilled labourer yet rising up to the respectability and worth of 'Mr. Society Steward'. (p. 189)

Black Theologian and biblical scholar Itumeleng Mosala commented on the topic of reconciliation and pointed out that Africans were, first and foremost, not alienated from white people but from their land, their cattle and themselves. The AICs provide an avenue for African self-definition by highlighting what is good about being African and inculcating a sense of pride in that identity.

It has been argued that AICs should be viewed as both African and Christian since they are innovations that draw on the elements of Christianity, African religion, Western culture as well as African culture and tradition (Kiernan 1990; Masondo 2005). Amongst the AICs, there is a greater appreciation of African culture, values and religion. Through their appreciation, they have managed to respond to the existential and spiritual needs of their followers in ways that are not alien to them. Barbara Bompani $(2008,2010)$, through her research in Soweto in 2001 and 2005, refuted the notion that the AICs were disinterested in politics. She was told by various AIC leaders that their focus was on local issues that affected their members on the ground. Theologian Simon
Maimela (1985) pointed out in his discussion of the concept of salvation in African Traditional Religion that:

The reluctance of Africans to break ties with the African Traditional Religions lies in the fact that they are wedded to an African worldview in which salvation is understood in terms of relief or help in times of trouble in this life. Salvation is thus expressed in such acts as healing, driving away evil spirits, empowerment of the individual self, the promotion of fertility, and success in life's ventures. (p. 72)

These African elements and motivations play a very important role in AIC theology and praxis.

African indigenous churches embraced African healing methods and modified them to suite their particular Christian context. Some try very hard to distinguish what they do from what the traditional healers do (Anderson 2003:181). However, the principle is the same. They both place much emphasis on dealing with a person's problem and the environment that led to the problem. Commenting on animal sacrifices amongst AICs in Lesotho, theologian Stan Nussbaum (1984:53) observed that, '[i]ndependent church thanksgiving sacrifices are not an attempt to accommodate something in the traditional religion but a new ritual considered to be definitely within a Christian context.' The end product is a result of reflection by Africans on African religions and cultural heritage and Christian teachings. AICs crafted a religion that reflected the influences of the above resources. The point has to be made that the AICs are not a replacement for African religion or orthodox Christianity. As Chidester (1989) says, they:

... are complex strategic negotiations in which symbolic forms are formulated, appropriated, manipulated, and mobilized to carve out a human identity and a place for that human to stand and to act as a human being. (p. 21)

Chidester (1992) pointed out that various white governments distrusted the Ethiopian church movement. In fact:

$\ldots$ in spite of its basically middle-class morals, values and aspirations, however, the Ethiopian movement was perceived by government as a threat simply by virtue of its independence from white control. (p. 119)

Various commissions were set up to investigate the activities of these churches, but they found no evidence to support the claim that they posed a danger to the state. The white establishment saw these churches as a threat to white religious and political hegemony. As a result, such initiatives by Africans were said to represent '... a Christian heresy, a political threat, and, ... a foolish desire to get rid of the white man's control' (Chidester 1997:323).

One of the reasons for the emergence of the Ethiopian spirit was the perception that missionaries were involved in the colonial schemes to subjugate Africans. Simensen (1987) points out that some Norwegian missionaries in Natal identified African independence as a stumbling block to Christianisation. They joined their English colleagues in supporting efforts to undermine Zulu independence through the use of force. 
Sundkler (1961), West (1975), and Kiernan (1990) reported the development of an urban Zionist phenomenon. These are small groups of between 20 and 30 people without a church building, meeting in the house of the leader. Chidester (1992) pointed out that, for the duration of the service, the house of the leader is transformed into a sacred space of worship and devotion for the faithful. There has not been any conclusive evidence that this model of church was adopted from the New Testament. The ability to transform mundane spaces into sacred spaces is an important element that led to the growth and spread of these churches.

\section{Resources for democracy and social cohesion}

\section{The Spirit}

\section{Spirit in African Traditional Religion}

African knowledge systems assert that reality is beyond human grasp. The Akan people of Ghana have a proverb that says: 'Wisdom is like a baobab tree and a single man's hand cannot embrace it' (Opoku 1993:67). This is an acknowledgement that reality is vast and complex, and no one or a single group can claim to understand it all. In other words, no single system of thought is capable of giving answers to all human questions. Theologian John Mbiti (1979) described the African as notoriously religious and argued that religion amongst Africans permeates into all departments of life so fully that it is not always easy or possible to isolate it. For him, all religions, except Christianity, constitute in the highest ideals a preparatio evangelica. Christianity provides an African with freedom, maturity, selfhood and fulfilment. This view has been discredited by a number of Africanist scholars in the field. Historian of religion Chirevo Kwenda (1997), in an introductory chapter to an annotated bibliography on African Traditional Religion in South Africa, challenged the notion that Africans are notoriously religious - are superstitious - and only respond to phenomena in an apparently 'irrational' manner. In fact, Mbiti's statement should have said 'notoriously spiritual'. There is a consciousness of the presence of the spiritual entity, given the understanding that the ancestors or the living-dead are forever watching the living and communicate with them through dreams, visions and visitations. African Theologian Gabriel Setiloane (1986:13) highlighted the spirituality of an individual person by pointing out that '... physically perceived the human person is like a live electric wire which is ever exuding force or energy in all direction'. The force or energy interacts with others from other people in a state of equilibrium. Death is perceived not as end of a person's existence but as a transition from physical to spiritual existence in the world of the ancestors. There are elaborate rituals associated with death. The protocols followed from the moment of death to the official end of the mourning period after a year are meant to provide a safe passage for the spirit of the departed to the spirit world and the eventual integration with the ancestors. This whole period is a liminal phase. It is marked with taboos and avoidances - it is a polluting stage which can potentially lead to negative consequences to those who fail to observe it, and it might also affect the whole community. The practice of $u$ kubuyisa [bringing-back the spirit of the deceased person after the period of mourning] also re-enforces this awareness. Furthermore, the growth of the house opening rituals in the South African urban areas underscores the significance that people place on the role of the spiritual in their lives (Masondo 2011:34-36). The isiZulu greeting Sawubona [we see you] also shows this awareness of the presence of the spiritual forces. The person is understood as being surrounded by a cloud of ancestors. The greeting acknowledges them.

Divination is a way of knowing, discerning and discovering the truth. In African thought, things are not always like they seem. There is always a story behind any event. For example when someone has an accident, there is a rational factual explanation of who and how many cars were involved, who was injured, the extent of damage to the vehicles, conditions under which the accident happened, witnesses, et cetera. Simultaneously, an appeal is made to the unseen reality who was behind the accident happening in the first place, and what were their intentions? How can one be protected from such things happening in future? The truth can only be uncovered through accessing the supernatural world. What happens in the seen world is formed and directed from the unseen world. The truth can only be uncovered by connecting to that world. The sacred specialists are the ones who are the key to unlocking the truth.

Experience during divination is when the diviner moves between the physical world and that of the spirits. In African tradition, women play a crucial role in the health of the community as diviners and healers. Such people have special contact with the ancestors and the spiritual realm. Since the ancestors are not confined by space and time, diviners have access to the past and the future. In that way, they are able to detect people's problems and devise ways to deal with them. Social anthropologist Harriet Ngubane (1976) formulated it in the following way:

The institution of divination provides another instance of a woman's marginality as she is a point of contact between 'this world' and 'the other world'. The diviner is not polluted with 'darkness' (umnyama). On the contrary she is in a state of light and purity. (p. 278)

Traditionally, Africans have respect for land. For Setiloane (1991), land is holy property as it does not belong to any individual but to God. Even chiefs do not own it but are trustees who distribute it to people in order for them to be able to make a living (Setiloane 1991:32). Land is also not seen as wealth like livestock since no one can possess it and exclude others from benefiting from its fruit. According to Mazamisa, the African understanding of land is similar to that of the Bible in some respects because it has both literal and symbolic intentions. The land is not only earthly turf, but '... it bears surpluses of meaning known only to those who lose and yearn for it' (Mazamisa 1993:5). He goes on to say that this is all encapsulated in the idea of ubuntu-botho which '... is essentially about historical placement in the earth, but 
that historical placement subsumes surplus meanings both rooted in and transcending literalism' (Mazamisa 1993:5).

For Africans, land is not simple real estate that could be bought and sold at will as it had no market value (Silitsena 1990:151). It has a much deeper meaning. It is the source of being for people, the basis on which people derive their identity because it is where their ancestors are buried. In the KwaZulu-Natal townships, when asked where they come from, people would say for example: 'Ngokuhlala ngiseMlazi, kodwa inkaba yami iseNkadla', which means: 'I live at Umlazi, but my umbilical cord is at Nkandla'. At Nkandla is where the roots are. The umbilical cord which had united the baby to its mother now symbolically unites or binds a person to a piece of ground. If this particular piece of land was to be sold, it would mean that the person would be rootless. Consequently, it is imperative that the land problem be resolved as a matter of urgency because there cannot be a stable political settlement without addressing this fundamental issue.

Clearly, black people's discourse about land is anti-language. It negates the fundamentals of the mainstream understanding of land as real estate with no surplus value attached to it. The fact that land is a haven and heaven for the ancestors is very important for the African understanding. It is their haven because it covers their shame, and it is a heaven because it is where they live and it influences the lives of the living.

\section{Spirit in AICs (Zionist type)}

The spirit is the life blood of AICs and the Newer Pentecostal Churches. It is the source of revelation, prophecy, illness detection, nature and impact of evil, knowledge concerning healing and knowledge concerning myth and ritual. It is also the transport between various realms of existence. It connects people to these realms of existence. Zionist Churches are the most prevalent form of the African Indigenous church movement in South Africa. Anderson \& Pillay (1997:227) report that, in 1991, Zionist-type churches and other African-initiated churches accounted for $40 \%$ of the black population. These churches put their emphasis on the Holy Spirit, divine healing, exorcism, prophecy, revelation and speaking in tongues. The central recruitment strategy of these churches is healing. Many people from the mainline churches (Methodist, Anglican, Presbyterian, et cetera) visit these churches for healing purposes and then return to their churches. The attraction is that it appeals to both Christianity and traditional forms of healing. The American Zionist movement started by John Alexander Dowie influenced the emergence of the Zionist church movement in South Africa. Dowie's movement sent missionaries to South Africa at the turn of the 20th century. The characteristics of Dowie's movement were (a) the prohibition of pork, (b) prohibition of tobacco, (c) prohibition of other medicines and (d) adult baptism through triple immersion (Chidester 1992).

The AICs are known as 'izinkonzo zomoya' (spirit churches or churches of the spirit). For me, such a designation constitutes theological mischief as it presupposes that other churches do not have or need the Holy Spirit. The Spirit in these churches is both desired and invited. At St John's, every congregation starts services by singing the song: 'Ngena nathi, asinawo amandla okungena sodwa' [start or enter with us, for we do not have power or strength to start or enter on our own]. In this way, they are actually inviting the Spirit to be there and manifest (Anderson 2003). Other AICs also spend a sizeable amount of time during their meetings on inviting the presence of the Spirit. Their services do not work without this important component. The Spirit is asked to participate in the event by influencing its direction. Without the presence of the Spirit, people are incapable of having a meaningful and successful service. The Spirit is expected to come and manifest itself in signs and wonders. The Spirit is experienced more during healing events. Its power is manifested in people falling down when touched by the prophet-healer or someone with healing powers. The presence of the Spirit is also demonstrated through dancing, crying, prophesying and speaking in tongues. Services are geared towards bringing and experiencing the presence of the spirit. This practice is drawn from the experience of the Apostles in Acts 2.

The spirit is an essential component of the healing and prophetic ministry of the AICs. It is responsible for all the prophecies that are shared at meetings. In fact, as Du Toit (1998) argued:

African Spirituality as expressed by black theologians is the experience of the Holy Spirit moving us and our communities to be life giving and life affirming. We celebrate our spirituality in songs, rituals and symbols which show the energizing spirit animating the community to move in response to God. (p. 47)

These churches do not have any links with missionary organisations or any foreign agencies. Women in these churches are more visible as prophetesses and healers. There have been a number of women who founded churches. The problem, however, is that, once the church starts attracting more people, a woman's leadership is not seen as adequate. Martin West observed amongst the AICs in Soweto that there was an unwritten rule that a woman cannot become leader of her church, no matter how powerful and gifted she might be. He cites two cases where women were dynamic leaders with powerful personalities and healing powers. In both cases, these women appointed their husbands as bishops. The husbands ended up leaving the running of the church to their wives because they did not have the charisma and gift of leadership. West (1975:52) referred to them as 'reluctant bishops' because, in most instances, they opened services with prayer and handed over to the wives to do the rest.

\section{Hope and self-belief}

The system of apartheid, through its laws and attempts at social engineering, led to the dehumanisation of the African self. The African was deliberately placed at the periphery of the economic centre, which led to serious deprivation. Africans were forced to live in the reserves, homelands, townships and other areas designated for them. The environment in these areas was not conducive for healthy living. It is within 
this context of deprivation and hopelessness that the AICs emerged. They provided for their members resources to engage with and survive these conditions. Lutheran black Theologian Manas Buthelezi, in developing his theology of liberation, insisted that the message of the Gospel had to be relevant to the existential needs of the people. The church needed to address issues of social justice, inequality, poverty and racism. In fact, he claims (Buthelezi 1978):

$\ldots$ it is as acts of Christian motivation become incarnate in the social, economic and political structures that we speak of Christian life as an everyday phenomenon. To dare to live for Christ means to have a Christian impact on these structures. It is a daring act because it involves the risk of suffering as Christ suffered as he made concrete his love for humanity. (p. 178)

The AICs proclaim that God is concerned with not only the salvation of the soul but with '... poverty, oppression, and liberation from affliction' (Anderson 2003:179). The AICs, through their rituals of healing and purification, were able to respond to people's existential needs and empower them to realise their personhood.

Anthropologists John and Jean Comaroff (2001) observed that, in the South African interior during the late colonial period amongst the southern Tswana, personhood was a social construct. For the southern Tswana, personhood could never be a state of being. A state of being assumes that something is static, fixed, unmoving and unchanging. A state of becoming, in contrast, refers to something dynamic, vibrant, full of life and active. As long as a person is alive, they never stop 'becoming'. Layer upon layer of who they are keeps on being removed - assuming that there are many facets to a person. Only powerful and anti-social agents are capable of stopping a person from becoming. In some cases, it is a question of being derailed or destructed, but one gets on the road again with the help of sacred specialists. This deviant behaviour is frowned upon yet at the same time feared. Deviant behaviour of any kind disturbs societal relationships and relationships between humans and divinity. This disturbance creates a state of disequilibrium, and chaos ensues. Chaos can take the form of illness or tension as a result of rape, death and other misfortunes. Traditionally, there were societal sanctions against deviant behaviour, depending on the severity of the action. In fact, personhood is constructed in two ways, as Comaroff and Comaroff (2001) noted:

... first, nobody existed or could be known except in relation and with reference to, even as part of, a wide array of significant others, and second, the identity of each and everyone was forged, cumulatively, by an infinite, ongoing series of practical activities. (p. 268)

Furthermore, 'selfhood was not ascribed: status and role were determined by factors other than birth or genealogy, although social standing was typically represented in genealogical terms' (Comaroff \& Comaroff 2001:268). The Tswana society is said to be at once highly communal and highly individuated. The process of acquiring one's personhood was an active process. People actively participate in the process of 'building themselves up'. The Comaroffs raise a crucial point that is often overlooked in some studies, namely that there are obstacles and opportunities in the process of identity construction. They burst the bubble of the myth of a harmonious African society by pointing out that there were social tensions that manifested in rivalries and eventually witchcraft accusations. The onus was on adult males, especially, to build themselves up and protect themselves from being eaten up by their enemies. The AICs provided tools to enable its members to navigate the hostile conditions of their environment and to restore them to their full humanity.

Anthropologist Linda Thomas (1994:52) observed a young man who, on his arrival at St John's, was reserved and withdrawn, but through interaction with others as well as participation in rituals, he became more confident, rose up the church hierarchy and found himself a job. It is apparent that participation in the healing activities and being involved with the church community restored his sense of self-worth and enhanced his self-confidence. Thomas further pointed out that the community credited the change in the boy's position to a supernatural source. In his submission to the Truth and Reconciliation Commission, Mthembeni Mpanza (1997) clearly stated that the cornerstone of the teachings of their leader Isaiah Shembe was hard work, self-discipline and self-reliance. These values are reflected in the liturgy for the morning service. The liturgy for the morning service might have been referring to an agricultural community in the 1920s and 1930s, but it is still very relevant to contemporary Nazarites as poverty, unemployment and disease are some of the issues that they contend with. They still have to rise up and work in order to extricate themselves from the shackles of poverty. The prayer is therefore an encouragement for them to go to their places of work to do the best they can in order to support their families and glorify God. From work, there was created an expectation of redemption, an idea which is consistent with Calvinist thinking and teachings on the value of work for salvation.

\section{Dealing with evil and misfortune}

The AICs have created an environment where real or perceived threats are dealt with by discovering the source of the threat, taking remedial action to ward off and neutralise what might be the cause of harm and, finally, constructing a 'security fence' to keep out evil (Anderson 2003:181; Oosthuizen 1988:12-13). Masondo (2013) made the point that the AICs provide us with a crisis model for managing change. Through their assortment of rituals, practices and procedures, they help their members to deal with crisis situations. Catherine Bell's insights on ritual are useful for our understanding of the role and place of ritual in the AICs. She said that '... in ritual activity, conceptions and dispositions are fused for the participants which yields meaning' (Bell 1992:28). This service is not only confined to their members as there are members of mission-initiated churches who secretly access these services and then return to their churches because '... the African prophet is providing pastoral care and oversight that is often inadequate or even absent in a 'mission church' context' (Anderson 2003:184). 
Witchcraft is an explanatory framework used to understand evil and misfortune. David Chidester defined witchcraft as anti-social behaviour. Witches are antisociety. They provide an alternative to the dominant constructions of society and civility. Their rules of engagement and operation do not conform to those of society. African pre-colonial history is littered with stories of how society discovered and dealt with witches. One of the most common ways was to 'smell-out' the witches. Once discovered a witch would either be executed or forced to flee the area. Witches are perceived to be antisocial, selfish and anti-morality. Firstly, they are said to be full of malice and evil designs as they have the capability to put the brakes on the development of another person's personhood. Secondly, witches act secretly at night and sometimes use witch familiars like baboons, hyenas and owls to carry out their plans. It is important to note that they are able to keep their activities secret from outsiders. Thirdly, they are capable of carrying out most of their evil plans because they possess extraordinary powers. These powers are anti-life and consume the life force of others. Through these powers, they are able to ukukhinyabeza (cripple) others, not allowing them to grow and flourish. Fourthly, since they are anti-society, they break societal and natural rules. They break societal taboos and engage in activities like incest, adultery, rape, abortion and bestiality. AICs have an assortment of rituals of inclusion and exclusion that are used to mediate and manage crises for their members.

\section{Community building}

Father J.B. Ngubane (1986) observed that:
... the independent churches have realized a community based at some centre and at the same time broken up into closely knit extended families in which every member has a sense of belonging. (p. 83)

The basis of any community is the core values and beliefs that each member has to adhere to. They are the social tissue that keeps the community together. The AICs have powerful rituals of inclusion that are used for the incorporation of new members into the group. Such rituals also confer an identity on those new members. The church as an established social institution has an established order, mode of operation as well as a social profile. Inclusion into the group is carefully managed in order for the candidate to fit into the group. The step by step tutoring, mentoring and instruction are meant to create an awareness of the expectations and responsibilities of membership. The work of Jean and John Comaroff (1989) on the colonisation of consciousness and the consciousness of colonisation is helpful in understanding how these churches made sense of their environment for their members. The AICs had consciousness of the presence of the 'other world' of unbelievers and oppressors. It is this consciousness and awareness that helped to shape their ideologies and responses. They instilled in their members what John Cumpsty (1986) called a sense of belonging. They actually create a 'home' for their members, something evidenced by the use of kinship terminology when referring to each other. At St John's, one leader referred to members of the congregation as abantwana bami bomoya [my spiritual children].

Each of these churches creates a closely knit community for its members that acts as a powerful support structure during times of need. G.C. Oosthuizen (1997) reported on some AICs in the Durban area that organise savings clubs for their members as a means of uplifting and empowering them.

Jim Kiernan, in his research at KwaMashu north of Durban, concluded that members of the AICs made good employees. Employers found them to be honest and reliable, and absenteeism was minimal, especially on Mondays, as they do not drink. Zionists at KwaMashu formed a close knit group. They gave each other support. Both Kiernan and West concluded on the basis of such mutual support that these churches replace rural kinship-support structures in the urban environment. The major focus of the group is to help each member to make a living in a very harsh and unforgiving urban environment. This point is further supported by the findings of Linda Thomas' research on St John's in Gugulethu.

\section{The prophetic}

Geoffrey Nelson (1987), echoing Max Weber's words, points out that prophets claim that their authority is derived directly from God. The claim on its own is not enough as it has to be legitimated through an extraordinary narrative, deeming the individual in question a special person or an anointed one. There has to be something extraordinary that sets this person apart from ordinary members of society. Such narratives create a mystique around the person thus confirming that she or he is called. Furthermore, the individual in question is said to be endowed with 'supernatural, superhuman or exceptional powers' (Dow 1969:306). Prophets are able to operate outside the realm of everyday routine. Their powers are able to defy rationality and logic. Partly, this is the attraction of this figure amongst the oppressed because they offer a radical solution to their problems without relying on the provisions of traditional logic. Moreover, 'by accepting or believing in the leader's extraordinary qualities, the followers legitimise his claim to their obedience' (Dow 1969:307). The narratives are then edged into the history and tradition of the group.

Prophets, like the ancestors, are seen as mediators between the people and God. Paul Makhubu (1988) noted:

The custom of not approaching the king or any senior person
directly, creates the mental attitude with which an African would
approach God. No ordinary man could talk to a king face-to-face.
This was considered to be extremely disrespectful, and carried a
heavy fine, or the death penalty, depending on circumstances.
In the same way God cannot be directly approached; someone
must act as a go-between. (p. 59) The designation of prophet includes both the biblical prophets as well as those who were responsible for the founding and growth of St John's. Prophets are 'gifted' people with a message that would help transform people's 
lives. However, prophets are not the final authority but mere conduits for the message of God. Talking about God in this way characterises Him to be the God of history. He is not only historical, but He is active in history, shaping St John's to be what it is today through messages and revelations given to his prophets at different times in history. Rev Mhlongo (n.d.) is at pains throughout his book to say that all the revelations to the prophet (Masango) have come to pass. Because of all this evidence of reliability, people can trust his God. The prophetic aspect in the AICs exposes the 'evil powers most feared in Africa: spirits, magic powers, disease and death' (Molobi \& Saayman 2006:334) and prescribes practical ways of combating and mediating their impact.

\section{Cultural justice}

The AICs address a critical point raised by Chirevo Kwenda in his reflection that cultural justice is a pathway to reconciliation and social cohesion. They affirm a particularly African Christian identity. In many ways, they are able to reconstruct and preserve some African cultural forms and traditions. Sam Gill (1994), in his critique of the academic study of religion, pointed out that one of its major problems is that it is based on a Western religious template where only those aspects that are prominent in Western religions are highlighted. He made an example of dance and related rituals. The AICs take dance seriously as part of their worship repertoire. Kwenda (2003) is of the opinion that:

... cultural injustice occurs when some people are forced, by coercion or persuasion, to submit to the burdensome condition of suspending - or more permanently surrendering - what they naturally take for granted, and then begin to depend on what someone else takes for granted. This means that, in reality, the subjugated person has no linguistic or cultural 'default drive', that critical minimum ways, customs, manners, gestures, and postures that facilitate uninhabited, unselfconscious action. (p. 70)

The AICs have played a key role as preservers, developers and promoters of African culture. According to Itumeleng Mosala (1985), these churches are a socio-cultural protest using precolonial African resources. They reject definitions of Christianity based on Western capitalist models. Mosala asserts a different kind of African identity, a dynamic one, which is firmly entrenched in historical and the sociological developments.

In her analysis of the Zionists amongst the southern Tswana, social anthropologist Jean Comaroff (1985) invoked the 'reaction to conquest' motif popularised by Monica Hunter Wilson (1961). She described their practice and religiosity as providing a response at a cultural and symbolic level to the brutal attack on Africans and their culture. She perceived it as a response to the destruction of African independent polities, the erosion of African practices and possible extinction of African culture. For her, the AICs challenged the notion of Christianity as a white man's religion, and they rejected the Hamitic myth of black subservience and inferiority to white people. Founders of the AICs like Shembe and Lekganyane proclaimed a Gospel of self-reliance and the utilisation of African resources for the development of their people. What is fascinating is that, in the process of creating new religions, founders were careful of what was included and excluded.

\section{Conclusion}

By appealing to the notion of cultural justice as an important condition for social cohesion in South Africa, one is able to understand how the AICs have employed various spiritual resources to define for their members a particularly African Christian identity. Cultural justice is not just about tolerance, but about treating other people's culture justly by accepting and respecting them, accepting the fact that these cultures have meaning for their adherents. Moreover, there has to be recognition of the potential of each of these cultures. They need to be given social and intellectual space to grow and thrive. Through some of their spiritual resources, the AICs have managed to preserve certain aspects of African tradition and culture. Chirevo Kwenda (1997) observed that there are two versions of African Traditional Religion (ATR). Firstly, the one version presented by the African elite is meant for a largely European and scholarly audience. In this version, the elite do everything to appease their audience. Secondly, Kwenda (1997) points out:

... the popular version of African traditional religion is what African ... do with no regard for what Westerners, or anyone else, may or may not think about it. It is what African do when they are just being Africans. (p. 2)

This characterisation of ATR applies to what the AICs do. They do their theology practically through dance, sharing testimonies, healing rituals, baptism, prayer and biblical exegesis. In their theology, the AICs do not subscribe to any authorised interpretation of the Bible. The suggestion by theologian C.M. Pauw (1995) that the AICs should be viewed as constituting a positive response to the gospel is useful for our analysis. This suggestion implies that Africans are active participants in carving out new ways of being or becoming Christian. The AICs provide a platform for members to know who they are. They also speak to and act on the existential needs of their members by providing them with coping mechanisms and strategies in a hostile and often dangerous environment.

\section{Acknowledgements Competing interests}

The author declares that he has no financial or personal relationship(s) that may have inappropriately influenced him in writing this article.

\section{References}

Anderson, A., 2003, 'African Initiated Churches of the Spirit and Pneumatology', Word and World 23(2), 178-186.

Anderson, A. \& Pillay, G.J., 1997, 'The segregated Spirit: The Pentecostals', in R. Elphick \& R. Davenport (eds.), Christianity in South Africa: A political, social and cultural history, pp. 227-241, David Philip, Cape Town.

Bell, C., 1992, Ritual theory, ritual practic, Oxford University Press, Oxford.

Bompani, B., 2008, 'African Independent Churches in Post-Apartheid South Africa: New political interpretations', Journal of Southern African Studies 34(3), 665-677. http://dx.doi.org/10.1080/03057070802259928

Bompani, B., 2010, 'Religion and development from below: Independent Christianity in South Africa', Journal of Religion in Africa 40(3), 307-330. http://dx.doi. org/10.1163/157006610X525435

Buthelezi, M., 1978, 'Daring to live for Christ', in H.-J. Becken (ed.), Relevant theology for Africa: Report on a consultation of Missiological Institute at Lutheran Theological College, Mapumulo, Natal, September 12-21, 1972, pp. 176-180, Lutheran Publishing House, Durban. 
Chidester, D., 1989, 'Worldview analysis of African Indigenous Churches', Journal for the Study of Religion 2(1), 15-29.

Chidester, D., 1992, Religions of South Africa, Routledge, London.

Chidester, D., 2000, 'Colonialism', in W. Braun \& R.T. McCutcheon (eds.), Guide to the study of religion, pp. 423-437, Cassell, London.

Chidester, D., 1997, 'Chistianity in South Africa', in D. Chidester, J. Tobler \& D. Wratten (eds.), Christianity in South Africa: An annotated bibliography, pp. 1-16, Greenwood Press, London.

Chipkin, I. \& Ngqulunga, B., 2008, 'Friends and family: Social cohesion in South Africa', Journal of Southern African Studies 34(1), 61-76. http://dx.doi. Africa', Journal of Southern Afric
org/10.1080/03057070701832882

Comaroff, J., 1985, Body of power spirit of resistance: The culture and history of a South African people, University of Chicago Press, Chicago.

Comaroff, J. \& Comaroff, J.L., 1989, 'The colonization of consciousness in South Africa', Economy and Society 18(3), 267-296. http://dx.doi. org/10.1080/03085148900000013

Comaroff, J.L. \& Comaroff, J., 2001, 'On personhood: An anthropological perspective from Africa', Social Identities 7(2), 267-283. http://dx.doi. org/10.1080/13504630120065310

Cumpsty, J.S., 1986, 'The religious location of Independent Churches and the New Religious Movements', in G.C. Oosthuizen (ed.), Religion alive: Studies in the new movements and indigenous churches in Southern Africa, pp. 1-20, Hodder and Stoughton, Johannesburg.

Dow, T.E., 1969, 'The theory of charisma', The Sociological Quarterly 10(3), 306-318. http://dx.doi.org/10.1111/j.1533-8525.1969.tb01294.x

Du Plessis, L.M., 2001, 'Freedom of or freedom from religion?: An overview of issues pertinent to the constitutional protection or religious rights and freedom in "the New South Africa"', Birmingham Young University Law Review 2, 439-466.

Du Toit, C., 1998, 'African spirituality and the poverty of Western religious experience', Journal of Theology for Southern Africa 100, 36-60.

Gill, S., 1994, 'The academic study of religion', Journal of the American Academy of Religion 62(4), 965-975. http://dx.doi.org/10.1093/jaarel/LXII.4.965

Hunter Wilson, M., 1961, Reaction to conquest: Effects of contact with Europeans on the Pondo of South Africa, Oxford U.P. for International African Institute, London.

Kiernan, J.P., 1990, The production and management of therapeutic power in Zionist Churches within a Zulu City, The Edwin Mellen Press, Lewiston.

Kwenda, C.V., 1997, 'African Traditional Religion', in D. Chidester, C. Kwenda, J. Tobler \& D. Wratten (eds.), African Traditional Religion in South Africa, pp. 1-9, Greenwood Press, Westport.

Kwenda, C.V., 2003, 'Cultural justice: The pathway to reconciliation and social cohesion', in D. Chidester, W. James \& P. Dexter (eds.), What holds us together: Social cohesion in South Africa, pp. 67-80, HSRC Press, Cape Town.

Maimela, S.S., 1985, 'Salvation in African traditional religions', Missionalia 13(2), 63-77.

Makhubu, P., 1988, Who are the independent churches?, Skotaville, Johannesburg.

Masondo, S., 2005, 'The history of African indigenous churches in scholarship', Journal for the Study of Religion 18(2), 89-103.

Masondo, S., 2011, 'The practice of African Traditional Religion in contemporary South Africa', in T.W. Bennett (ed.), Traditional African Religions in South African Law, pp. 19-36, UCT Press, Cape Town.

Masondo, S., 2013, 'The crisis model for managing change in African Christianity: The Story of St John's Apostolic Church', Exchange 42(2), 155-172. http://dx.doi. org/10.1163/1572543X-12341262

Mazamisa, W.L., 1993, "'Umhlaba" and the ethics of reparation', unpublished paper presented at UCT African Studies Seminar program.
Mbiti, J.S., 1979, 'The Biblical basis for present trends in African Theology', in K. Appiah-Kubi \& S. Torres (eds.), African Theology en route, pp. 83-94, Orbis Books, Appiah-Kubi\&
Maryknoll.

Mhlongo, J.B., n.d., Umprofethi wodumo: The life of Prophet Petros John Masango, Matprint Litho, Witbank.

Molobi, V. \& Saayman, W., 2006, 'A time for complementarity: African Theology, Black Theology and the AICs', Missionalia 34(2/3), 324-337.

Moosa, E., 2000, 'Tensions in legal and religious values in the 1996 South African Constitution', in M. Mamdani (ed.), Beyond rights talk and cultural talk, pp. 121135 , David Philip, Cape Town.

Mpanza, M.P., 1997, Submission to the Truth and Reconciliation Commission by Ibandla lamaNazaretha on the 18th November 1997, East London.

Mosala, I., 1985, 'African Independent Churches: A study of socio-theological protest', in J.W. de Gruchy \& C. Villa-Vicencio (eds.), Resistance and hope: South African Essays in honour of Beyers Naude, pp. 103-111, Wm. Eerdmans, Grand Rapids.

Nelson, G.K., 1987, Cults, new religions and religious creativity, Routledge and Kegan Paul, London.

Ngubane, H., 1976, 'Some notions of "purity" and "impurity" among the Zulu', Africa 46(3), 274-284. http://dx.doi.org/10.2307/1159399

Ngubane, J.B., 1986, 'Theological roots of African Independent Churches and their challenge to Black Theology', in I.J. Mosala \& B. Thagale (eds.), The unquestionable right to be free: Essays in Black Theology, pp. 71-90, Skotaville Publishers, Johannesburg.

Nsibande, A.E., 1992, 'The Black theologian and the Black Church', in H.L. Nelson, P.S. Lwandle \& V.M. Keding (eds.), Dynamic African theology: Umphumulo's contribution, pp. 26-30, Pinetown Printers, Durban.

Nussbaum, S., 1984, 'Rethinking animal sacrifice: A response to some Sotho Independent Churches', Missionalia 12(2), 49-63.

Oosthuizen, G.C., 1997, African Independent Churches and small businesses: A spiritual support for secular empowerment, Nermic report, University of Zululand.

Oosthuizen, G.C., 1988, 'Interpretation of demonic powers in Southern African Independent Churches', Missiology: An International Review 16(1), 1-22.

Opoku, K.A., 1993, 'African traditional religion: An enduring heritage', in J. Olupona \& S. Nyang (eds.), Religious plurality in Africa: Essays in honour of John S Mbiti, pp. 67-82, Mouton De Gruyter, New York, Berlin.

Pauw, C.M., 1995, 'African independent churches as a "people's response" to the Christian message', Journal for the Study of Religion 8(1), 3-25.

Setiloane, G.M., 1986, 'The contribution of the Methodist Church to the African indigenous church movement', in G.C. Oosthuizen (ed.), Religion alive: Studies in the new movements and indigenous churches in Southern Africa, pp. 186-196, Hodder and Stoughton, Johannesburg.

Setiloane, G.M., 1991, 'Land in the negotiations chamber: An Afro-centric approach', Journal of Black Theology in South Africa 5(2), 29-39.

Silitsena, R., 1990, 'Impact of colonialism on land use in Central and Southern Africa', in P.A. Olson (ed.), The struggle for land: Indigenous insight and industrial empire in P.A. Olson (ed.), The struggle for land: Indigenous insight and ind
in the semiarid world, pp. 146-170, University of Nebraska, Lincoln.

Simensen, J., 1987, 'Religious change as transaction: The Norwegian mission to Zululand, South Africa, 1850-1906', in K.H. Petersen (ed.), Religion, Development and African Identity, pp. 85-104, Scandanavian Institute of African Studies, Uppsala.

Sundkler, B., 1961, Bantu prophets in South Africa, Lutherworth Press, London.

Thomas, L.E., 1994, 'African Indigenous Churches as a Source of Socio-Political Transformation in South Africa', Africa Today 41(1), 39-56.

Thomas, L., 1999, Under the canopy: Ritual process and spiritual resilience in South Africa, University of South Carolina Press, Columbia.

West, M.E., 1975, Bishops and prophets in a Black City: African Independent Churches in Soweto, Johannesburg, David Philip, Cape Town. 